\title{
THE CRITICAL INCIDENT TECHNIQUE IN PHYSIOTHERAPY EDUCATION
}

\author{
JOHLYNE C. BEENHAKKER, B.Sc. (Physio) (Witwatersrand) D.P.E. (Witwatersrand)*
}

Report of a pilot study undertaken to determine the behaviour of an effective physiotherapist. The critical incident technique was used to collect data from 30 practising physiotherapists and 300 separate incidents of effective and ineffective behaviour were identified. On the basis of this study, the desirability of objectively identifying curriculum content in physiotherapy education has been established.

One of the problems facing physiotherapy educators today is what should be taught and what should be deleted from the rapidly expanding undergraduate curriculum. We must establish whether the present syllabus is meeting the needs of the society in which the physiotherapist will practice and ensure that the needs of the students are also being met.

Of the many studies that have been done by the various professions, one of the most promising methods of determining curriculum content appears to be the critical incident technique.

By incident is meant a unit of observable human activity which is sufficiently complete in itself to allow inferences to be made about the person performing the act. A critical incident is one which leaves the reader little doubt regarding its effectiveness or ineffectiveness. The critical incident technique was evolved by flanagan (1954) and he has used it as a basis for studies in many varied fields. Jensen (1960) and Barham (1963) have applied the technique to different aspects of Nursing and a large study in Orthopaedic training was described by Miller (1968). In these studies, practitioners in the various professions were asked to describe a situation, record what action was taken by the person observed and what the result of the action was. Once the incidents had been collected, it was possible to identify the key actions of the profession being studied.

A pilot study was carried out by the Physiotherapy Department of the University of the Witwatersrand to determine whether the critical incident technique would be a practicable method of establishing what behaviours characterise an effective physiotherapist.

\section{METHOD}

Six physiotherapy colleagues were chosen to carry out the study and each was asked to approach five senior physiotherapists representing hospital and private practitioners, as well as those from special institutions

* Senior Lecturer, Acting Head, Sub-Department of Physiotherapy, University of the Witwatersrand. Received 11 January 1980.

\section{Opsomming}

Verslag van 'n voorlopige studie wat onderneem is om die gedrag van ' $n$ doeltreffende fisioterapeut vas te stel. Die kritiese insident tegniek is gebruik om data van 30 praktiserende fisioterapeute te versamel en 300 aparte insidente van doeltreffende en ondoeltreffende gedrag is geidentifiseer. Op grond van hierdie studie is die wenslikheid van objektiewe identifisering van kurrikuluminhoud in fisioterapie-onderrig vasgestel.

and training centres. There were eight physiotherapists from private practice, five from cerebral palsy schools and institutions, thirteen in hospital employ and four at training centres, who took part in the study. These 30 physiotherapists were given 10 forms each in which to report incidents which they considered to have had a positive or negative outcome, as regards effectiveness. To ensure the collection of a full spectrum of behaviours in the cognitive, psychomotor and affective domain, the areas suggested for collection of the incidents were:-

- Interpersonal relatıonship with the patient, his family or other members of the health team.

- Intellectual - use of problem solving and other skills in the assessment of the patient or situation as well as the planning of a treatment programme.

- Technical - methods of carrying out the assess. ment or treatment programme.

Of the 300 forms given out, 180 were returned in time for the study which was limited to an initial six week period. As several of the forms had more than one reported incident, 300 examples were collected which fell under two or more of the main areas. Each incident was extracted from the form and recorded on a separate card.

The first analysis of the data was done in June, 1979, when 194 incidents were identified. In July, a further 106 incidents were categorised and of these only one was found to be a new behaviour (Table I).

Each main area was subdivided according to the incidents, and as new behaviours were received, new sub-areas were formed, e.g. A-I-Relationship with patient (a) Listens to patient, (b) Explains to patient, (c) Gains patient's co-operation etc.

\section{ANALYSIS OF DATA}

The validity of the interpretation and classification of the incidents was checked by submitting a random sample of the cards to two of the co-workers. These workers then sorted out the cards under the various areas and it was found that there was a ninety-five per cent agreement in their classification as compared 
TABLE I

\section{CLASSIFICATION OF INCIDENTS}

\section{- Area}

June 1979 July 1979

\section{A Interpersonal}

I Relationship with patient 46

II Relationship with family 24

III Relationship with health team 24

B Assessment

C Treatment

$\frac{59}{194} \frac{27}{105}-86$

\section{*EFFECTIVE/INEFFECTIVE}

From your experience, think of a recent situation in which you observed or you did something which illustrated an adequate/inadequate* performance by a physiotherapist.

1. Briefly describe the background to the incident.

2. How experienced was the physiotherapist? Years since qualification.

3. How experienced was the observer?

4. Describe exactly what the physiotherapist did.

5. What more effective/ineffective* behaviour might be expected in a similar situation?

6. Where was the observation made? Please tick the appropriate block.

General Hospital Special School Private Practice Special Institution Other

- Please delete the one which is not appropriate.

to mine. This reasonably high correlation led me to assume that a panel of three judges would be sufficient to sort out and categorise the incidents in the main study to be done in 1980. In order to check the reliability of the classification system, I re-classified a sample of the incidents two months after completion of the study.

\section{DISCUSSION}

From the favourable results of the pilot study, a full study is being planned in which physiotherapists from different parts of the country will take part. Additional information will be gathered concerning the institution or practice in which the observation was made and the length of time since qualification of the observer.

A random sample of about 200 physiotherapists will be approached, the number representing approximately $1 / 5$ of the total number of practising physiotherapists in South Africa. These will be drawn from different areas to ensure that all fields in which a physiotherapist practises, are covered.

Incidents will be collected and classified until no more than one new behaviour is reported in every 100 incidents examined, in order that a sufficiently large and representative sample of behaviours is obtained.

Once all the incidents have been collected and classified, a list of effective and ineffective behaviours wily be drawn up.

From these specific observable behaviours, it is intended that a full set of learning objectives will be established.

By establishing the kind of behaviour a student should achieve to demonstrate professional competency, a curriculum can be planned which will meet society's needs. This will ensure that the curriculum which has evolved somewhat haphazardly over the years, is based on a more secure and scientific foundation.

The initial classification of 194 incidents was done in June, from the first 106 returned forms. In July a further 74 forms were analysed and from the 105 incidents extracted, only one new incident which required an additional sub-area was found.

\section{References}

1. Barham, Virginia Z. (1963). Identifying effective behaviour of the nursing instructor through critical incidents. Ed. D. Dissertation. University of California, Berkely.

2. Flanagan, John C. (1954). The critical incident technique Psychological Bulletin 51, 4.

3. Jensen, Alfred C. (1960). Determining critical requirements for nurses Nursing Research 9, 1.

4. Miller, George E. (1968). The orthopaedic training study J. Amer. Med. Assoc., 206, 3. 